\title{
CD44 is required for two consecutive steps in HGF/c-Met signaling
}

\author{
Véronique Orian-Rousseau, Linfeng Chen, Jonathan P. Sleeman, Peter Herrlich, and Helmut Ponta ${ }^{1}$ \\ Forschungszentrum Karlsruhe, Institute of Toxicology and Genetics, D-76021 Karlsruhe, Germany
}

\begin{abstract}
The tyrosine kinase receptor c-Met and its ligand HGF/SF, ezrin, and splice variants of CD44 have independently been identified as tumor metastasis-associated proteins. We now show that these proteins cooperate. A CD44 isoform containing variant exon v6 sequences is strictly required for c-Met activation by HGF/SF in rat and human carcinoma cells, in established cell lines as well as in primary keratinocytes. CD44v6-deficient tumor cells were unable to activate c-Met unless they were transfected with a CD44v6-bearing isoform. Antibodies to two v6-encoded epitopes inhibited autophosphorylation of c-Met by interfering with the formation of a complex formed by c-Met, CD44v6, and HGF/SF. In addition, signal transduction from activated c-Met to MEK and Erk required the presence of the cytoplasmic tail of CD44 including a binding motif for ERM proteins. This suggests a role for ERM proteins and possibly their link to the cortical actin cytoskeleton in signal transfer.
\end{abstract}

[Keywords: CD44 splice variants; ezrin; Gab-1; invasiveness; scattering]

Supplemental material is available online at http://www.genesdev.org.

Received July 19, 2002; revised version accepted October 4, 2002.

The receptor tyrosine kinase c-Met (here designated Met) and its ligand hepatocyte growth factor/scatter factor HGF/SF (here designated HGF) control several cellular processes essential for life. Disruption of their genes in the mouse causes embryonic death in midgestation, due to placental failure, and reduced development of several epithelial organs (for review, see Birchmeier and Gherardi 1998). Analyses of these mice and studies of organ and cell cultures revealed roles for HGF/Met in invasive growth and cellular migration, in proliferation and differentiation, and in mesenchymal-epithelial communication, as well as in tubular epithelial organization and morphogenesis (for review, see Bardelli and Comoglio 1997; Birchmeier and Gherardi 1998). Met is predominantly expressed in epithelial cells, whereas HGF is secreted by mesenchymal cells. HGF can bind to heparan sulfate proteoglycans (HSPGs; Mizuno et al. 1994), but it is controversial as to whether the function of HSPG binding is needed for the signaling process. In CD44transfected Namalwa cells, HGF binding to a CD44HSPG enhanced Met activation (van der Voort et al. 1999), whereas in MDCK and mink lung cells, an HGF mutant which cannot bind to heparan sulfate (HS) activated Met just like the wild type (Hartmann et al. 1998).

${ }^{1}$ Corresponding author.

E-MAIL genetik@itg.fzk.de; FAX 49-7247-823354.

Article and publication are at http://www.genesdev.org/cgi/doi/10.1101/ gad.242602.
Cancer cells subvert the HGF/Met system. In oncogenic Tpr-Met, for instance, the "negatively acting membrane-proximal domain" of Met is replaced by the dimerization helix of $\mathrm{Tpr}$, thus causing ligand-independent Met activation and oncogenesis (Rodrigues and Park 1993; Vigna et al. 1999|. Met promotes the invasive and metastatic properties of tumor cells in several animal systems (Giordano et al. 1993; Rong et al. 1994). In various human tumors, gene amplification of met, up-regulation of Met expression, and mutations in met have been detected (for review, see Bardelli et al. 1997).

Invasive and metastatic growth is not only influenced by HGF/Met. Other growth factors, the extracellular matrix, the functional state of adhesion molecules and that of their intracellular complexes are also important determinants (Habets et al. 1994; Camenisch et al. 2000; Hobson et al. 2001). Genome-wide unbiased screens, for example by suppressive subtractive hybridization, identified numerous metastasis-associated genes (Nestl et al. 2001). Interestingly, Met, ezrin, metalloproteases (MMPs), and urokinase plasminogen activator (uPA) receptor were found overexpressed in several types of metastatic cancer cells.

One of the earliest screens for metastasis-associated genes identified variant isoforms of CD44 (Günthert et al. 1991). The designation CD44 describes a family of class I transmembrane proteins produced by extensive alternative splicing. The variation is predominantly in the extracellular membrane-proximal portion of the proteins encoded by variant exons v1 to v10. An additional 
CD44 is an obligatory coreceptor for c-Met

degree of variability of CD44 is introduced by posttranslational modifications (for review, see Naor et al. 1997; Ponta and Herrlich 1998).

A causal role for CD44 isoforms in the formation of metastases has been documented by ectopic expression in certain nonmetastatic cell lines. Isoforms bearing sequences encoded by exons v4 through v7 or v6 plus v7 (CD44v4-7 and CD44v6,7 respectively) sufficed to confer metastatic potential to these cells (Günthert et al. 1991; Rudy et al. 1993). Antibodies directed against a v6-encoded epitope or CD44v6 antisense abrogated tumor growth and metastatic outgrowth in vivo and invasiveness of fibrosarcoma cells in vitro (for review, see Naor et al. 1997; Ponta and Herrlich 1998).

CD44 null mice are viable and show very circumscribed deficiencies, for example of the immune system and of cell migration in the embryo (Schmits et al. 1997; Protin et al. 1999; see also the discussion section in Camenisch et al. 2000). Our current hypothesis, and that of others, is that efficient substitute molecules take over CD44 functions in early embryonic development but that substitution cannot be established after differentiation. This notion is supported by the observations that perinatal antisense CD44 expression in keratinocytes or antibody interference with CD44 function in the differentiated cells of the apical ectodermal ridge during limb development caused severe defects related to inhibited growth factor function (Kaya et al. 1997; Sherman et al. 1998). As a possible mechanism for the action of CD44, the sequestering and "presentation" of growth factors by CD44 was suggested (Tanaka et al. 1993; Bennett et al. 1995). Several growth factors, FGFs as prime examples, bind to HS, and their receptors require HS association for signaling (Schlessinger et al. 1995; Plotnikov et al. 1999). HS can indeed be covalently linked to CD44, predominantly or exclusively to a sequence motif encoded by exon v3. CD44v3 could thus function in FGF "presentation" (Sherman et al. 1998).

The up-regulation of CD44 variant proteins and of Met in cancer as well as possible roles for both types of molecules in metastatic growth and invasion prompted us to examine a possible molecular interplay between them. We show here that in several types of cells including primary keratinocytes, HGF-induced Met activation and signaling depends absolutely on the presence of CD44 isoforms bearing the $\mathrm{v} 6$ sequence. HS modification of CD44 is not required for this synergy. Mature HGF, Met, and v6-containing CD44 proteins form a complex. Met activation as well as complex formation is prevented by antibodies recognizing the v6 epitope or other epitopes in the membrane-proximal stem structure of CD44. Interestingly, CD44v6-containing isoforms catalyze two distinct and separable steps during HGF-dependent Met signaling. For Met autophosphorylation, the extracellular domain of CD44 is required and sufficient. Transfer of the signal from activated Met to MEK and Erk depends, however, on the presence of the cytoplasmic tail of CD44 and most likely its associated actin-binding protein ezrin, suggesting a role of the cytoskeletal organization in signal transduction.

\section{Results \\ Met activation and HGF-dependent scattering and chemotaxis require the function of a CD44 variant isoform}

To explore a possible synergy between CD44 and Met, we chose two metastatic cell lines, BSp73ASML (here designated ASML) and HT29, which both express several CD44 variant proteins and Met. For both cell lines, a tumor-promoting role of CD44 variant isoforms has already been demonstrated (Günthert et al. 1991; Reeder et al. 1998). Antibodies to a v6-encoded epitope interfered with tumor growth and metastasis (Seiter et al. 1993; Sleeman et al. 1996a). If CD44 and Met cooperate, these antibodies might interfere with Met signaling.

To test this assumption, we starved ASML and HT29 cells, then treated them with HGF in the presence or absence of v6-specific antibodies (note that the epitopes recognized by the antibodies to rat and human v6 differ; Khaldoyanidi et al. 2002). Phosphorylation of Met was identified by Western blot analysis (Fig. 1A). Whereas HGF treatment led to an increase in Met tyrosine phosphorylation, v6-specific antibodies completely abolished this activation. Similar data were obtained with other immortalized cell lines such as 293 cells /data not shown). Thus, a CD44 protein is absolutely required for Met autophosphorylation in several cell lines.

To explore whether a CD44 variant isoform is also required for the activation of Met in nontransformed cells, we examined primary human keratinocytes. In these cells the activation of Met upon treatment with HGF (three- to sevenfold in three different experiments) could be blocked consistently with CD44v6-specific antibodies to a level of $50 \%$ (Fig. 1A).

The absence of any phosphotyrosine on Met after treatment with antibodies against the v6 epitope suggests that all downstream targets are affected by the antibody treatment. This is indeed the case, as shown here for signal transduction to Erk (Fig. 1A) and for HGF-dependent scattering and invasiveness (Fig. 1B,C). The specificity of the $\mathrm{v} 6$ inhibition is demonstrated by the fact that isotype-matched antibodies recognizing an $\mathrm{N}$ terminal CD44 domain (IM7 and J173) and the 5G8 antibody recognizing only the smallest CD44 isoform (CD44s) but not the variant forms expressed in ASML cells were inactive. All CD44v transcripts in ASML cells lack exon 15 (Günthert et al. 1991), which encodes the epitope recognized by antibody 5G8.

This result stresses that it is a CD44 variant isoform comprising the v6 epitope which cooperates with Met. Interestingly, the anti-v3 antibody BBA11 had no effect on scattering (data not shown), suggesting that exon v3 was not involved in cellular processes induced by active HGF.

\section{CD44 isoforms bearing exon v6 are necessary and sufficient for the cooperation with $\mathrm{Met}$}

To explore which variant isoforms cooperate with Met, we first limited the study to the two tumor cell lines, 

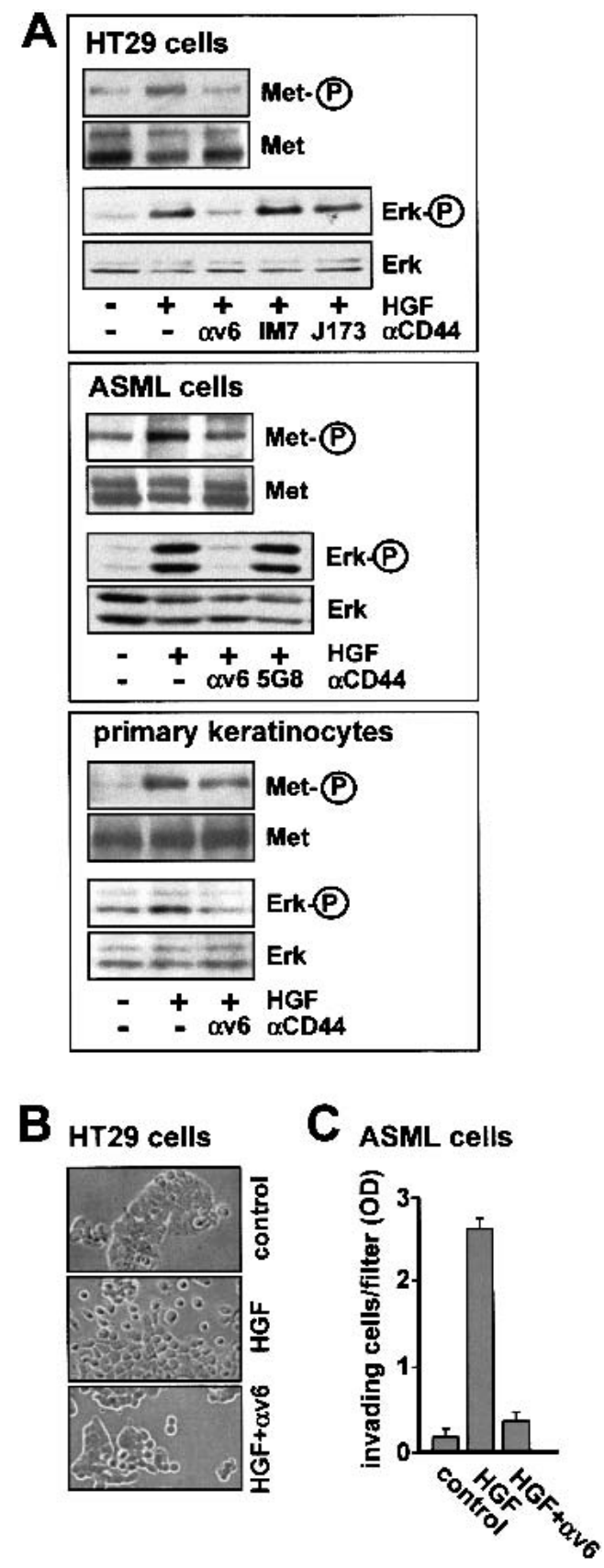

Figure 1. A CD44 variant isoform is required for Met activation. (A) HT29, ASML cells, and primary keratinocytes were each induced with HGF for $5 \mathrm{~min}$ in the presence or absence of antibodies (for HT29 cells and keratinocytes, $\alpha \mathrm{V} 6$ was BIWA; for ASML cells $\alpha \mathrm{v} 6$ was 1.1ASML). Subsequently, Met or Erk phosphorylations were determined (see Materials and Methods). (B) HT29 cells grown in the absence (control) or presence of HGF with or without antibodies directed against CD44v6 (BIWA) were visualized by phase contrast microscopy. Magnification, 40×. (C) Invasion of ASML cells into Matrigel was measured in the absence (control) or presence of HGF with or without antibodies directed against CD44v6 (1.1ASML). Each point represents the average of three independent determinations \pm S.D. and we analyzed which CD44 molecules they express and thus could be potential candidates for the cooperation. Exon-specific RT-PCR (van Weering et al. 1993) permits the determination of both the structure and the approximate abundance of the isoforms (Fig. 2). The "ladder" obtained with the variant exon-specific primers (van Weering et al. 1993; König et al. 1996) in combination with the size of each product demonstrates the structure of the CD44 isoforms. The approximate abundance of isoform transcripts can be estimated from the intensity and size of bands obtained with the constant region primers (Fig. 2, lane labeled C).

HT29 cells mainly express the four isoforms CD44v410, CD44v2,3,8-10, CD44v2,9,10, and CD44s (Fig. 2). The predominant CD44 isoforms in ASML cells are CD44v4-7, CD44v6,7, and CD44s. Minor species are CD44v8-10 and possibly CD44v2-7.

In both cell lines, several isoforms thus carry the epitopes encoded by exon v6, to which the inhibitory antibodies bind. To now specifically define which CD44 variant isoforms synergize with Met, we transfected expression constructs encoding individual CD44 isoforms (Fig. 3A) into noninvasive, nonscattering, and nonmeta-

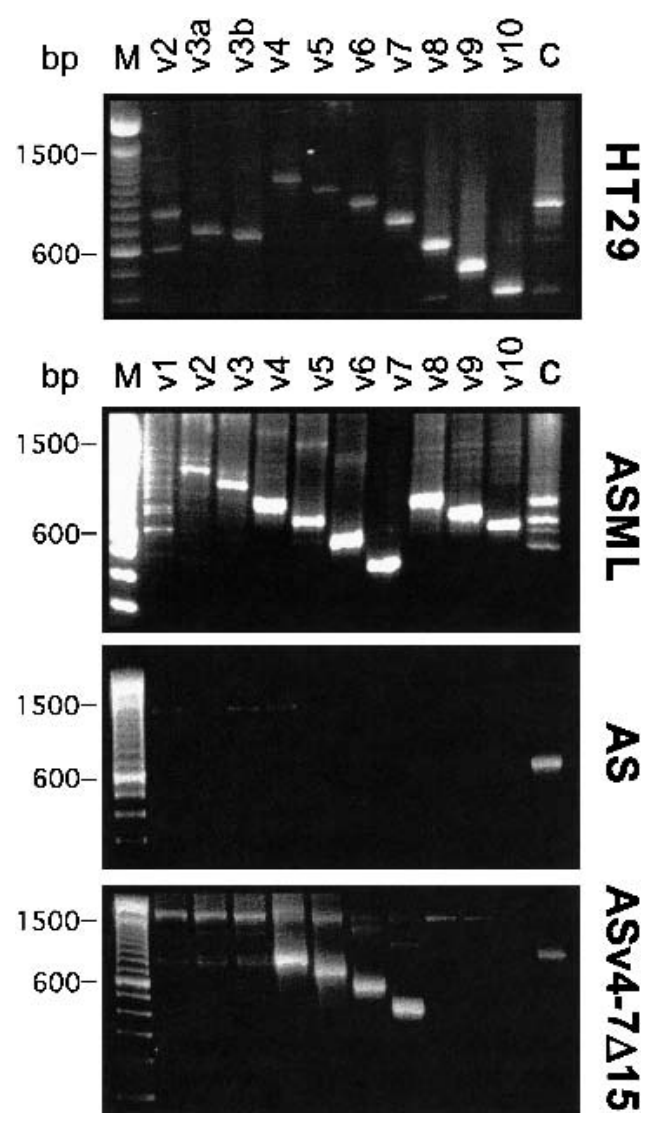

Figure 2. Exon-specific RT-PCR analysis of CD44 isoforms in various cell lines. RT-PCR analyses with mRNA derived from the cells indicated were performed with CD44 exon-specific primers as described (van Weering et al. 1993; König et al. 1996). The marker lane (M) shows a 100-bp DNA ladder (Life Technologies). 
A
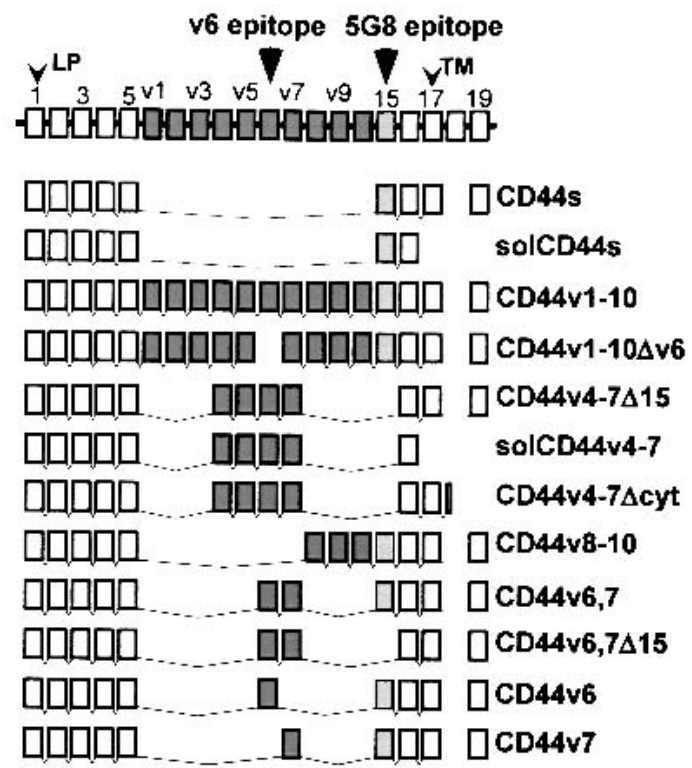

C

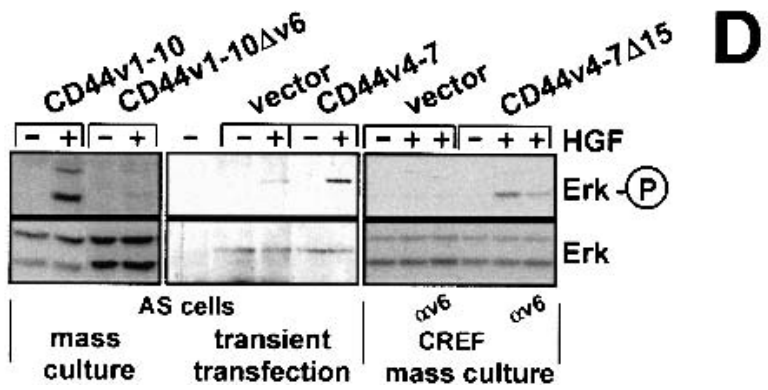

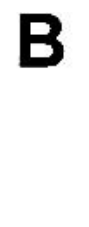
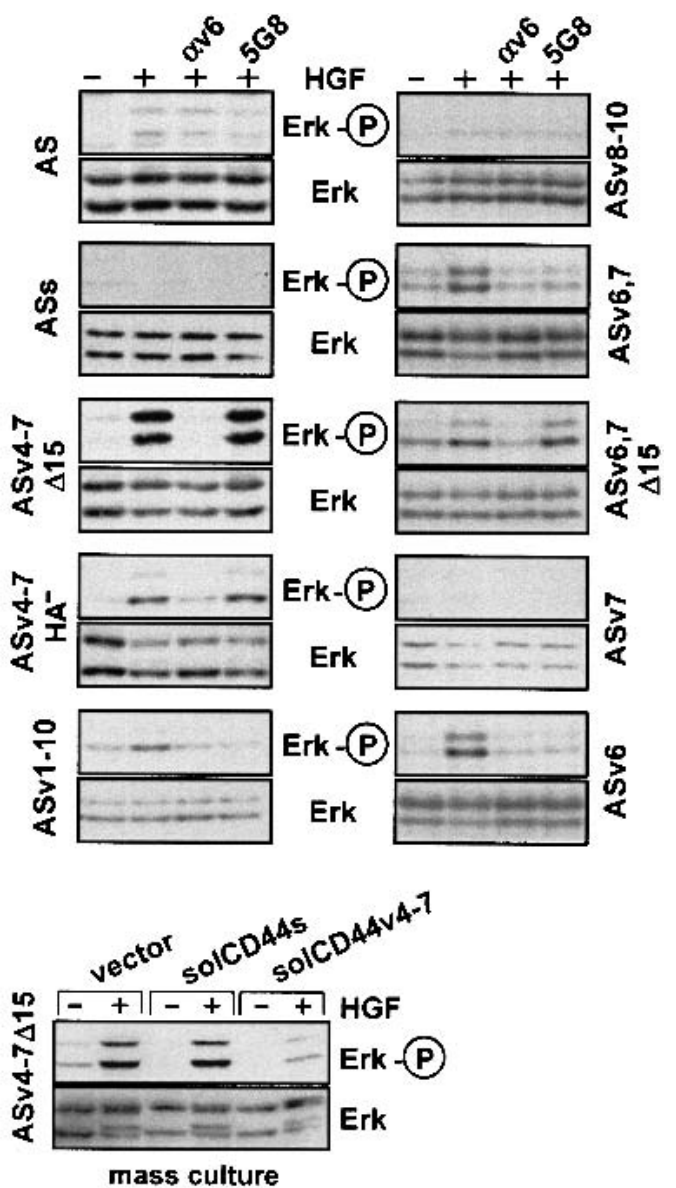

Figure 3. CD44 isoforms containing the exon v6 sequence are required for Met activation. (A) Schematic representation of CD44 isoform structures. Constant region exons are numbered 1-5 and 15-19, variant exons v1-v10. LP, leader peptide; TM, transmembrane region. (B) Activation of Met in AS cells stably transfected with various CD44 isoforms was measured using phosphorylation of Erk as readout. The loading controls were performed by stripping the phospho-Erk blot and reprobing with an anti-Erk antibody. ASs indicates transfectants with CD44s, ASv4-7 15 cells stands for transfectants with CD44v4-7 with an exon 15 deletion, and ASv4$7 \mathrm{HA}^{-}$indicates cells transfected with a CD44 isoform containing a point mutation in the major hyaluronate (HA) binding site (Sleeman et al. 1997). Other transfectants are designated according to the CD44 variants used for transfection. (C) CREF or AS cells were stably transfected with CD44 constructs (Günthert et al. 1991 and as indicated) together with a plasmid harboring the puromycin resistance gene, and were grown as mass cultures. AS cells were transiently transfected with CD44v4-v7 (or vector) together with a hemagglutinin-tagged Erk (see Materials and Methods). Determination of Erk activation in response to HGF treatment is described in Materials and Methods. (D) ASv4-7 15 cells were transfected with the indicated constructs, and puromycin resistant clones were selected as mass cultures.

static BSp73AS cells (abbreviated AS; Günthert et al. 1991). These cells express levels of Met comparable to those in ASML cells (data not shown), but exclusively express CD44s (Fig. 2). An example of RT-PCR analysis of a CD44v4-7 transfectant is shown in Figure 2. In the parental cells, Met signaling is barely activated by HGF, as determined by phosphorylation of Erk (Fig. 3B, panel 1). Additional overexpression of CD44s did not enhance the response (Fig. 3B, panel 2). However, HGF-dependent Met phosphorylation (see Fig. 7, below; data not shown) and Erk activation (Fig. 3B) were fully supported by all CD44 variants bearing the exon v6 sequence, including a CD44 protein containing v6 alone $(\mathrm{CD} 44 \mathrm{v} 6$; Fig. 3B panel 10). Furthermore, a CD44 isoform containing all variant exons except v6 did not support Met activation (Fig. 3C). These results were obtained with stably transfected cell lines (independent clones revealed the same result, data not shown). They were confirmed by transient transfection experiments using cotransfection of CD44 isoform expression constructs and hemagglutinintagged Erk (an example is shown in Fig. 3C) and stably transfected mass cultures (an example is shown in Fig. $3 \mathrm{C})$ to rule out clonal variation. Furthermore, in two other tumor cell lines, BDX2 (Sleeman et al. 1996a) and CREF (Fisher et al. 1982), both fibroblast cell lines that express Met, activation of Met was also strictly dependent on transfection of CD44v6-containing isoforms (shown for CREF in Fig. 3C). 
The cell lines analyzed also included transfectants expressing v6-containing CD44 containing or lacking exon 15 (epitope for 5G8). Lack or presence of exon 15 had no influence on the cooperation of v6-containing CD44 proteins with Met. However, HGF-dependent Erk phosphorylation could be inhibited by 5G8 antibodies in cases where the exon 15 sequence was present (Fig. 3B). Both v6 and exon 15 sequences make up the membraneproximal stem structure of these variant isoforms. Antibodies to the membrane-distal $\mathrm{N}$ terminus of CD44, however, did not affect the CD44-Met cooperation (Fig. $1 \mathrm{~A}$; data not shown). Consistent with this result, mutation of the major hyaluronate binding site in the $\mathrm{N}$ terminus (hyaluronate is the main ligand of CD44) did not disturb the cooperation with Met (Fig. 3B, panel 4). We conclude from the analysis of the different transfectants that the presence of the v6 sequence is necessary and sufficient for Met signaling.

A putative interaction of the $\mathrm{v} 6$ sequence with a ligand could possibly be blocked by offering an excess of the extracellular domain as a soluble protein. We and others have shown that such treatment can interfere with several CD44 functions (for review, see Naor et al. 1997; Morrison et al. 2001). Overexpression of a secreted CD44 isoform bearing $\mathrm{v} 6$ sequences in ASv4-7 15 cells (HGFresponsive, Fig. 3B) inhibited HGF/SF-dependent Erk activation, whereas that of an isoform lacking $\mathrm{v} 6$ did not (Fig. 3D). These results confirm the specificity of v6bearing CD44 in c-Met activation and, in addition, suggest that the protein must be membrane-bound to support c-Met function.

Heparan sulfate modification of CD44 is not required for Met activation by HGF

Since HGF can bind to HSPGs (Mizuno et al. 1994), we considered whether modification of CD44 could be a prerequisite for HGF-mediated activation of Met. This is, however, made unlikely by our finding that CD44 molecules bearing only exon $\mathrm{v} 6$ sufficed to confer signaling competence. Exon v6 (in contrast to exon v3; Bennett et al. 1995) does not encode an HS addition site. To ascertain that no HS modification elsewhere in the molecule (or even on other surface molecules) was responsible for HGF-mediated Met activation, we examined Erk phosphorylation upon HGF treatment in cells in which HS had been removed by heparinase treatment. Heparinase II treatment of cells had no influence on HGF-induced Erk activation (shown for HT29 cells and for AS cells transfected with CD44 variant expression constructs, Fig. 4A), even though the enzyme removed more than $95 \%$ of HS side chains from the cell surface, as judged by FACS analysis using an HS-specific antibody (data not shown).

To substantiate these results, direct analysis of HSmodifications on CD44 proteins was performed using an antibody which recognizes heparan stubs $(\Delta \mathrm{HS})$ following digestion with heparinase. The antibody precipitated CD44 proteins only if they had been modified by HS addition prior to heparinase treatment. Heparan stub im-
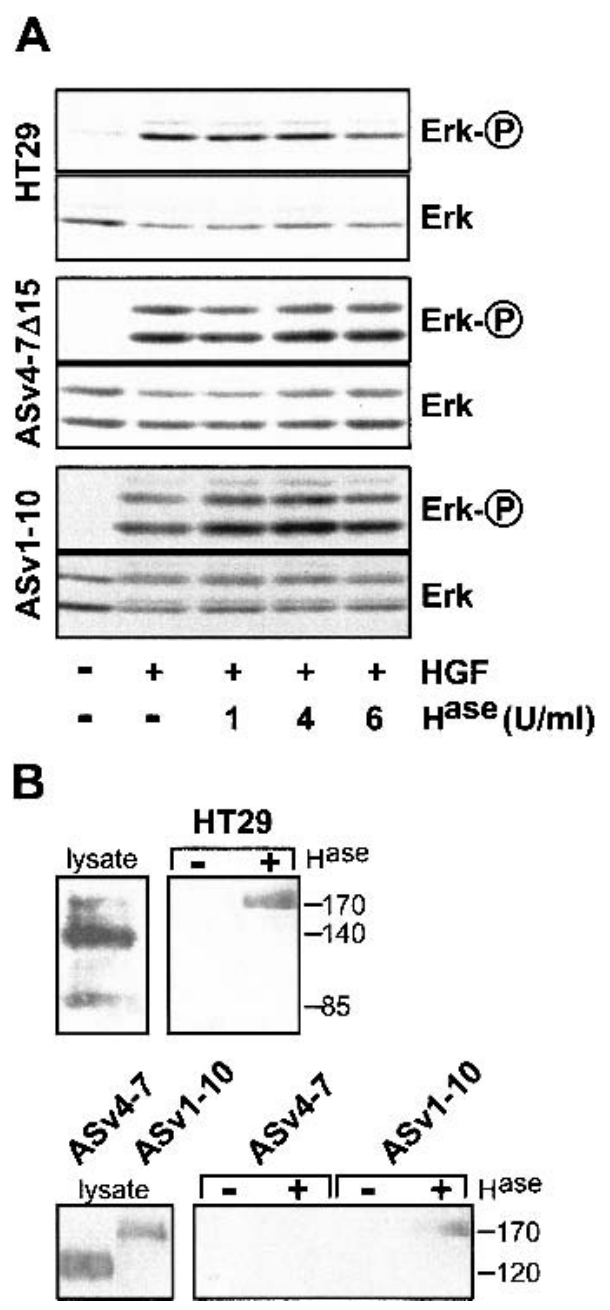

Figure 4. Heparan sulfation of CD44 is not required for Met signaling. (A) HGF-induced Erk phosphorylation was measured in HT29, ASv4-7 15 , and ASv1-10 cells. Where indicated, cells were pretreated with heparinase II $\left(\mathrm{H}^{\text {ase }}\right)$ at $37^{\circ} \mathrm{C}$ for $3 \mathrm{~h}$ prior to HGF addition. (B) Western blot analyses using a $\Delta$ HS antibody are shown in the right panels. Where indicated, cells had been pretreated with heparinase II $(6 \mathrm{U} / \mathrm{mL})$ at $37^{\circ} \mathrm{C}$ for $3 \mathrm{~h}$. The lysates were probed by Western blotting using Hermes 3 (for HT29 cells) or 5G8 (for AS transfectants) antibodies.

munoprecipitates were resolved by PAGE and subjected to Western blot analysis using CD44-specific antibodies. From lysates of AS cells expressing isoforms lacking exon v3, for example, CD44v4-7, no CD44 could be precipitated by the stub antibody (Fig. 4B), indicating that these isoforms had not been modified by heparan sulfate. As a positive control, a v3-containing isoform was readily precipitated from lysates of CD44v1-10-transfected AS cells (Fig. 4B). From lysates of HT29 cells, the major CD44 protein species could not be precipitated, but a minor large isoform was (Fig. 4B). HT29 cells thus carry HS-modified and nonmodified CD44 proteins. Taken together, the results support the notion that CD44 proteins lacking HS side chains cooperate with HGF in the activation of Met. 
CD44 does not mediate cleavage of pro-HGF to active $H G F \alpha$ and $\beta$

How do CD44 isoforms bearing the v6 sequence support Met signaling? A plausible hypothesis was suggested by experiments showing that the proform of TGF $\beta 1$ can be activated through recruitment of the protease MMP-9 by CD44 (Yu and Stamenkovic 1999). Like TGFß1, HGF is secreted as a single-chain precursor (proform) which is processed to the biologically active (S-S-linked) $\alpha$ and $\beta$ subunits by serum proteinases (Naka et al. 1992) or by uPA (Naldini et al. 1992). To explore a possible activation of HGF by CD44, we attempted to activate Met using $90 \%$-enriched precursor HGF either as a commercially available preparation or as our own HGF proform produced in Drosophila Schneider cells (Fig. 5A). In the absence of serum (all activation experiments were done with serum-starved cells), the proform was unable to activate Met signaling to Erk despite the presence of competent CD44 isoforms (Fig. 5B,C). Even after prolonged incubation, no cleavage of HGF proform was detected (data not shown). As expected, pro-HGF was readily processed by incubation with serum (Fig. 5A). In contrast to the data with pro-HGF, Met signaling by processed HGF was supported by competent CD44 isoforms (Fig. 5B,C). We conclude that cleavage of the HGF proform is not the mechanism of CD44-Met cooperation in our cell systems.

\section{CD44v6 isoforms, Met, and HGF associate into multimeric complexes}

The finding that the stimulation of Met by CD44 is supported only by mature HGF suggests close proximity of all three partners. In coculture experiments with Metexpressing AS cells (expressing no v6-containing isoform) and Met-negative CD44v3-10-expressing Namalwa cells (van der Voort et al. 1995), we observed that the cooperating molecules need to be located on the same cell (data not shown). To document close association of Met, CD44, and HGF in the same cellular membrane, coimmunoprecipitations were performed using HT29 and AS cells transfected with CD44v6 (ASv6). Cells were incubated with biotinylated HGF, treated with the crosslinker dithiobis-sulfosuccinimidylpropionate (DTSSP), then lysed and immunoprecipitated. The precipitates were resolved by SDS-PAGE under reducing conditions. With HT29 cells, the major CD44 isoform (140 kD) coprecipitated with anti-HGF and anti-Met antibodies (Fig. 6A). If cells had not been treated with HGF, CD44 could not be precipitated with Met (Fig. 6A). HGF (as detected using avidin) coprecipitated with Met and CD44 (Fig. 6A, lower panel). With ASv6 cells, anti-Met antibodies precipitated only the v6-containing isoform, not CD44s (Fig. 6B). Biotinylated HGF coprecipitated with CD44v6 (data not shown). To show that complex formation was not a peculiarity of tumor cells, we examined also immortalized MDCK cells. CD44 antibodies that cross-react with canine CD44 (Trowbridge et al. 1982) precipitated biotinylated HGF from MDCK cells (Fig. 6B).

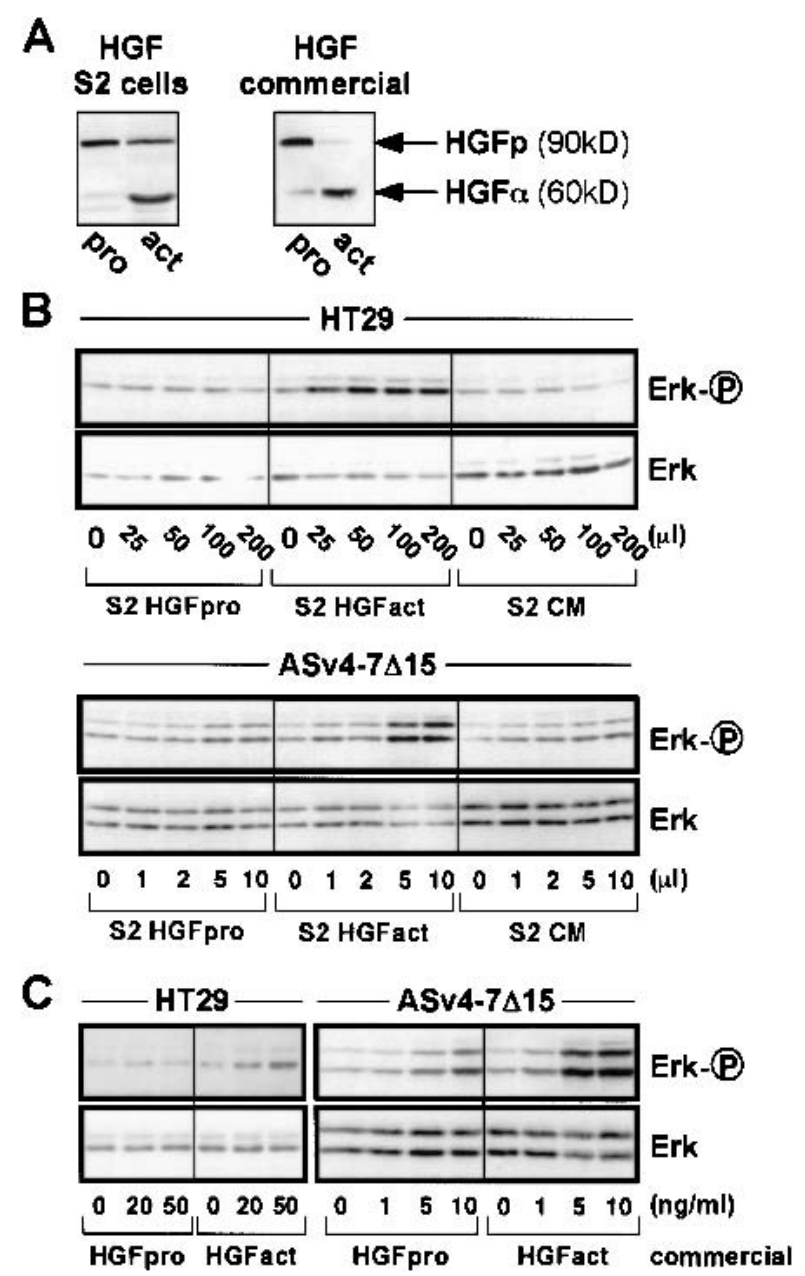

Figure 5. HGF proform is activated by neither HT29 cells nor transfected AS cells. (A) HGF proform produced by Drosophila Schneider cells (S2 cells) as well as commercial pro-HGF were activated by incubation with $5 \%$ serum at $37^{\circ} \mathrm{C}$ overnight. HGF pro- and activated forms are visualized by Western blotting with anti-HGF $\alpha$ antibody. $(B)$ Increasing amounts of conditioned medium from mock-transfected S2 cells (CM) or S2 cells transfected with an HGF expression vector and grown in the absence of serum (S2 HGFpro) or in the presence of $5 \%$ FCS (S2 HGFact) were used to treat HT29 cells or ASv4-7 15 cells. (C) Commercially available pro-HGF prior to and after activation (see $A$ ) was used to stimulate HT29 and ASv4-7 15 cells. We explain the slight induction of Erk phosphorylation at higher concentrations of HGF proform in the case of the very sensitive CD44v47-transfected AS cells by the presence of traces of activated HGF in the proform preparations.

In the absence of excess thiols, a large DTSSP-crosslinked protein complex with an estimated mass of more than $600 \mathrm{kD}$ was resolved by SDS-PAGE (under nonreducing conditions) from lysates of ASv6 cells (Fig. 6C). To examine its contents, the complex was cut out of the gel and applied to a second SDS gel under reducing conditions to disrupt the cross-links. After Western blotting of the gel, the three components of biotinylated HGF, CD44v6, and Met were detected using avidin or specific antibodies (Fig. 6C). This multimeric complex was not 
Figure 6. CD44, Met, and HGF form a multimeric complex. (A) Western blots with anti-CD44 antibodies or with avidin of immunoprecipitates (IP) from HT29 cells treated with HGF where indicated, and cross-linked with DTSSP (see Materials and Methods; multimeric complex precipitations were also obtained without prior cross-linking; data not shown). For preclearing [precl(HGF)], lysates were immunoprecipitated with anti-HGF antibodies, and the supernatant was again immunoprecipitated with anti-HGF $\alpha$. Rabbit IgG is a control antibody. $(B)$ Western blots (5G8 antibodies) of immunoprecipitates from ASv6 cells $(7.5 \%$ gel) and immunoprecipitates from MDCK cells using avidin for detection of biotinylated HGF (10\% gel). (C) Immunoprecipitates of ASv6 or AS lysates using Met-specific antibodies were resolved under nonreducing conditions by SDS-PAGE (10\%). A single band was identified that stained with either avidin (shown here) or antibodies directed against Met or CD44 (data not shown). The band was excised from the gel, incubated with dithiothreitol and rerun on SDS-PAGE. Western blots with avidin, 5G8 $(\alpha \mathrm{CD} 44)$, and $\alpha$ Met are shown. $(D)$ Western blot for Met expression in lysates of ASv6 or AS cells. (E) Same procedure as in A. For immunoprecipitations, IM7 or control antibodies were used. Where indicated, cells were incubated with BIWA antibodies or IM7 at $37^{\circ} \mathrm{C}$ for 5 min prior to induction with biotinylated HGF.

found in cells expressing only CD44s (Fig. 6C), even though the cells carried at least the same amount of Met (Fig. 6D).

The above data indicate the existence of an inducible multimeric complex comprising at least CD44, HGF, and Met. The induced formation of the immunoprecipitable complex (here precipitated by IM7 recognizing the $\mathrm{N}$ terminus of CD44) was prevented by prior addition of antibodies directed against the exon $\mathrm{v} 6$ epitope, but not by antibodies specific for the $\mathrm{N}$-terminal domain of CD44 (IM7; Fig. 6E). Thus, irrespective of the putative presence of other components in the complex, CD44v6 is essential for its formation. Thus, four independent experimental approaches indicate $\mathrm{CD} 44 \mathrm{v} 6$ specificity in Met activation: inhibition by anti-v6 antibodies, lack of Met activation in v6-negative cells and restoration by transfection with CD44 bearing v6, interference by v6containing peptides, and identification of a multimeric complex composed of Met, HGF, and CD44v6.

\section{A two-step mechanism of CD44-Met cooperation}

Formation of the complex appeared to result from properties of the extracellular domains. To test whether the extracellular part of CD44 bearing the v6 sequence suffices to promote Met activation, we analyzed AS cells transfected with a mutant lacking the cytoplasmic tail of CD44v4-7. The tailless mutant protein indeed permitted
HGF-induced phosphorylation of Met, just like the fulllength molecule (Fig. 7A) and this was again inhibitable by v6 antibodies (data not shown). The tailless mutant also permitted HGF-induced phosphorylation of Gab1 (Fig. 7A) and PLC $\gamma$ (data not shown). These data indicate proper activation of Met. To our great surprise, however, the tailless CD44 mutant did not support MEK and Erk phosphorylation (Fig. 7A). Thus we conclude that competent CD44 isoforms promote Met signaling in two consecutive steps: formation of the multimeric complex needed to cause autophosphorylation of Met, followed by a second step in which the signal from the receptor and its adaptor proteins is transferred to MEK and downstream signaling components.

The second step in Met signaling that is dependent on the cytoplasmic tail of CD44 must obviously be linked to the cooperating CD44 variant isoform, because the presence of excess amounts of CD44s did not compensate for the lack of the tail on the variant isoform (the CD44v4-7 $\Delta$ cyt transfectants carry more CD44s than the CD44v4-7 $\Delta$ cyt isoform). How could the tail promote signal transfer? We speculated that proteins assembled at the tail might be responsible. To this end, we transiently overexpressed the cytoplasmic tail of CD44 fused to GST in order to sequester putative binding partners away from the endogenous CD44 molecules. For these experiments we chose the human embryonal kidney cell line 293 for its high transient transfection efficiency $(>80 \%)$. 


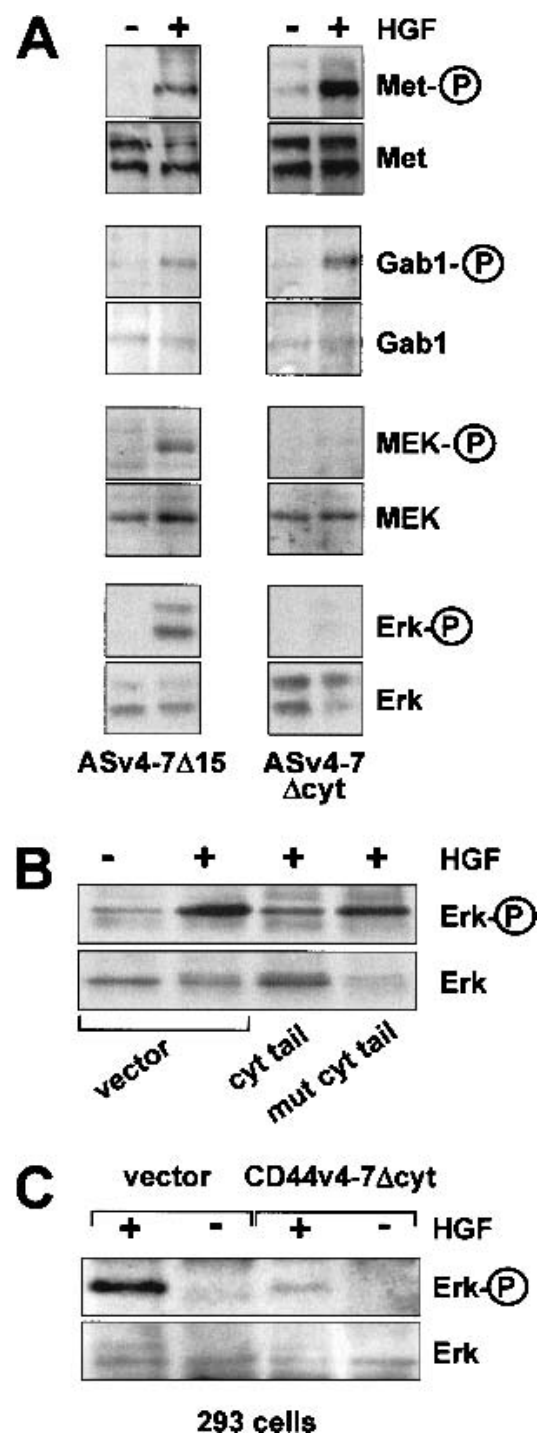

Figure 7. The CD44 cytoplasmic tail is required for Met signaling, but not for Met activation. (A) In ASv4-7 cells or cells transfected with a cytoplasmic tail deletion (ASv4-7 $\Delta$ cyt), Met, Gab1, MEK, and Erk activation were determined. (B) Here, 293 cells were transiently cotransfected at a ratio of $1: 15$ with a hemagglutinin-tagged Erk construct and plasmids expressing GST fused to the cytoplasmic tail of CD44 or a mutant thereof, respectively (Morrison et al. 2001). Twenty-four hours after transfection, cells were starved for $10 \mathrm{~h}$ and then induced with HGF as indicated. Tagged Erk was immunoprecipitated, and phosphorylation of Erk was determined. (C) The ASv4-7 $\Delta$ cyt construct (or vector alone) was transiently transfected into 293 cells, and Erk activation upon HGF treatment was determined.

We first made certain that the CD44/Met system existed and functioned in these cells. Indeed, 293 cells express several CD44 variants (see König et al. 1996), and HGF induces Met signaling (Fig. 7B) that can be inhibited by v6 antibodies (data not shown). Upon overexpression of the cytoplasmic tails of CD44, the signaling to Erk was, however, inhibited (Fig. 7B). Furthermore, a CD44v6containing mutant lacking the cytoplasmic tail acted as dominant negative in these 293 cells (Fig. 7C). We conclude that proteins essential for signal transfer were sequestered away from their location of normal function, from the transmembrane protein CD44.

The cytoplasmic tail of CD44 carries a binding site for ERM proteins (Legg and Isacke 1998) which link the actin cytoskeleton to transmembrane proteins (for review, see Tsukita and Yonemura 1999). To investigate whether an ERM protein participated in the signal transfer, we overexpressed in 293 cells at similar abundance the wild-type cytoplasmic CD44 tail or the tail mutated in the ERM binding site. The mutated tails could not interfere with Met-dependent signaling (Fig. 7B). The second step of CD44-Met cooperation thus involves most likely a reaction promoted by an ERM protein, and this cytoplasmic assembly must be part of the multimeric complex for successful downstream signaling by Met.

\section{Discussion}

Invasiveness and metastatic migration of cancer cells are in part regulated by the receptor tyrosine kinase Met. Met can be activated by mutation, but most frequently depends on stimulation by its ligand HGF produced either by the tumor cells or by stromal cells (for review, see Bardelli et al. 1997). Here we have shown in several different transformed and nontransformed cells that activation of Met by its authentic ligand HGF depends strictly on the function of CD44 isoforms that carry the exon v6-encoded protein sequence. The contribution of CD44 is twofold: The extracellular domain of CD44 with the $\mathrm{v} 6$ sequence is required to organize a ternary complex between Met, HGF, and CD44 which is a prerequisite for Met activation. The cytoplasmic tail of the v6-containing CD44 isoform assembles protein partners necessary for signal transfer from Met to MEK and Erk. Sequestration experiments using soluble cytoplasmic tail peptides indicated that ERM proteins are necessary as protein partners in the signaling process (ezrin is the major ERM member in our tumor cells). Our data thus identify a mechanistic link between four molecules that have been implicated in tumor metastasis formation: HGF/Met (for review, see Bardelli et al. 1997), CD44 (for review, see Naor et al. 1997), and ezrin (Fazioli et al. 1993).

How can the extracellular domain of CD44 variant proteins support Met activation? We and others have reported previously that HS-binding growth factors such as FGFs profit from the presence of large CD44 splice forms which act as HSPGs (Bennett et al. 1995; Sherman et al. 1998). The v3 sequence carries the unique HS-addition site of CD44 and was required for FGF action. HGF can also bind to HS, and a supportive effect of CD44HSPG on Met activation has been found on Namalwa cells (van der Voort et al. 1999). An HGF mutant which cannot bind to HS was, however, not defective in its Met-activating potential but rather exhibited enhanced activity (Hartmann et al. 1998). In addition, in our cell lines, neither the v3 exon-associated HS nor any other HSPG 
was needed for CD44-dependent Met activation in response to added mature HGF.

As we excluded an activation of the HGF proform by CD44, two interpretations remain to explain the role of the v6-dependent clustering in the activation of Met. Either HGF requires CD44 help to bind to Met, or v6bearing CD44 prevents access of a negatively acting component to Met. Negative components acting on Met could be specific transmembrane or cytosolic protein tyrosine phosphatases interacting with Met (Kulas et al. 1996; Villa-Moruzzi et al. 1998). Indeed, negative control appears to be eliminated in constitutivly active oncogenic Tpr-Met, where the extracellular domain of Met and an intracellular "negative domain" are lost (Vigna et al. 1999). We currently favor the interpretation that a negative regulator is excluded. Apparently, for this function CD44 needs to be anchored in the plasma membrane, because a soluble CD44v6-containing isoform does not support Met activation but rather inhibits it (Fig. 3C).

The close proximity of Met and CD44 mediated by v6 appears, in addition, to be important for a second step of synergy absolutely required for HGF-induced signaling. The cytoplasmic tail of CD44 potentiates signal transduction from the multimeric complex. Our data suggest that an essential partner protein is ezrin (or another member of the ERM family), although other proteins with similar binding preference are not strictly ruled out. Ezrin can link the actin cytoskeleton to the plasma membrane through binding of its $\mathrm{C}$ terminus to F-actin, and of its $\mathrm{N}$ terminus to CD44 (for review, see Tsukita and Yonemura 1999). For this function, ezrin needs to be phosphorylated which, interestingly, can also occur in a Met-dependent reaction (Crepaldi et al. 1997). Lack of the cytoplasmic tail of CD44 or the sequestering of ezrin away from its location by excess soluble CD44 tails in the cytoplasm caused block of HGF-induced signal transfer, as well as disruption of cortical actin (data not shown). We interpret this finding to indicate a need for structural organization of the cytoskeleton in the immediate proximity of Met which is mediated by ezrin. The CD44v6 isoform focusses the signaling components specifically to Met. Interestingly, replacement of ezrin by the tumor suppressor protein merlin (Morrison et al. 2001) also caused disruption of cortical actin structure and a block of signal transduction $(\mathrm{H}$. Morrison, $\mathrm{H}$. Ponta, and P. Herrlich, unpubl.).

The idea that a strict structural organization at the inner side of the plasma membrane controls signal transduction is supported by several other observations. The presence of $\alpha$-catenin bound to E-cadherin appears to exert a negative control on signal transduction downstream of receptor tyrosine kinases, but upstream of Ras (Vasioukhin et al. 2001). $\alpha$-catenin links E-cadherin to F-actin. Ankyrin, which also bridges CD44 to the cytoskeleton, was found to recruit Src into the complex (Bourguignon et al. 2001). The view that signaling components are strictly organized in a preformed order as modules emerges from various data, for example, the existence of scaffolding proteins and the confined localiza- tion of c-AMP, PKA, and phosphodiesterase (Whitmarsh et al. 1998; Yasuda et al. 1999).

Although our data show a requirement for CD44 in HGF-induced Met signaling in a number of transformed and nontransformed cell lines, several lines of evidence suggest that CD44 is not globally required for this signaling. For example, we have observed that HGF is able to induce Met signaling in HepG2 cells, which do not express CD44, and in fibroblasts derived from CD44 null mice (L. Chen, V. Orian-Rousseau, P. Herrlich, and H. Ponta, unpubl.). In these cells, Met activation cannot be blocked by CD44v6-specific antibodies. Whether Met is able to signal independently of accessory proteins in these cells, or whether other molecules act as coreceptors in these circumstances, remains to be determined. We have obtained preliminary data that revealed that some proteins coimmunoprecipitate with Met from CD44-negative cells but not from CD44-positive cells. As pointed out earlier in this article, several observations suggest that substitute molecules can compensate for the absence of CD44 in CD44 null mice, probably accounting for why CD44 null mice are viable, whereas the targeted deletion of Met is embryonic lethal.

CD44 was originally identified as an adhesion molecule that binds to ECM components (for review, see Naor et al. 1997; Ponta et al. 1998). In addition to the synergizing pair CD44/Met, other receptor tyrosine kinases are associated with adhesion molecules. Interactions have been described between ErbB2 and CD44s (Bourguignon et al. 1997; Sherman et al. 2000), and between FGF receptor 4, N-cadherin, and N-CAM (Cavallaro et al. 2001). Intriguingly, CD44 and integrins also seem to be linked in that they coordinately affect the binding to cells of another invasiveness-associated molecule, osteopontin, and in that cross-linking of CD44 up-regulates integrin activity (Fujisaki et al. 1999; Katagiri et al. 1999). In turn, the activation of Met up-regulates expression of osteopontin (Medico et al. 2001), presumably increasing expression of CD44 and perhaps even regulating alternative splicing through activation of Ras (Hofmann et al. 1993; König et al. 1998). These examples suggest the existence of a network of protein complexes in the plasma membrane and of several regulatory loops. Interestingly, in cells lacking the integrin subunit $\beta 4$, Met could not be activated (Trusolino et al. 2001). Met signaling could be re-established by the introduction of $\beta 4$, which was found to associate with Met. The possibility thus exists that $\alpha 6 \beta 4$ integrin, CD44, and Met are located in one and the same membrane domain.

Why should the activation of a growth factor receptor depend on a cooperating transmembrane protein? A plausible explanation was recently suggested by the finding that CD44 monitors the cellular environment through its N-terminal domain (Morrison et al. 2001). Cell-cell contact and the presence of high-molecularweight hyaluronate affected the activity state of CD44, which resulted in a change in intracellular partner proteins and had a dramatic effect on signal transduction and gene expression (H. Morrison, H. Ponta, and P. Herrlich, unpubl.). The formation of multicomponent com- 
plexes at the cell surface could be the first decisive step that determines the programs leading to proliferation, migration, invasiveness, or cell cycle arrest.

\section{Material and methods}

\section{Cells}

The human colon adenocarcinoma cell line HT29, a generous gift from A. Zweibaum (INSERM) and the CREF cells (Fisher et al. 1982) were grown in Dulbecco's modified Eagle's medium (DMEM, Life Technologies) with 10\% fetal calf serum (FCS; PAA). The rat pancreatic carcinoma cell lines BSp73ASML and BSp73AS10 (here designated as ASML and AS, respectively; (Matzku et al. 1983) and their transfectants were grown in RPMI medium (PAA) with $10 \%$ FCS. Generation and properties of AS cell clones that had been transfected with various CD44 expression constructs have been described (Rudy et al. 1993; Seiter et al. 1993; Hudson et al. 1995; Sleeman et al. 1996b, 1997).

The human kidney cell line 293 (accession no. CRL-1573) and the Drosophila Schneider S2 cells (accession no. CRL-1363) were purchased from ATCC and cultured in the media recommended. The MDCK cells were a generous gift from W. Birchmeier (Max Delbrück Center, Berlin, Germany). They were grown as described (Behrens et al. 1989). Human keratinocytes were purchased from BioWhittaker and cultured according to the instructions.

\section{Transfection}

Transfection of 293 cells was performed by electroporation. Cells were seeded at $1 \times 10^{7}$ cells $/ 25 \mathrm{~cm}$ plate. Twenty-four hours later, cells were harvested and suspended in $400 \mu \mathrm{L}$ PBS, and $16 \mu \mathrm{g}$ of DNA was added. Electroporation was performed in a 2-mm electroporation cuvette using a Gene Pulser (Bio-Rad) at $250 \mathrm{mF}, 0.45 \mathrm{kV}$. Cells were collected in $1 \mathrm{~mL}$ of medium and plated on $10-\mathrm{cm}$ plates. Transient transfection of AS cells was performed using Tfx50 (Promega) according to the manufacturer's instructions.

\section{Constructs}

To obtain an expression construct containing CD44v8-10, the plasmid pCMV-DIabc-V that encodes rat CD44v1-10 (Hudson et al. 1995) was converted into a CMV-promoter-driven CD44v8-10 construct. The construct CD44v1-104v6 was obtained from CD44v1-10 by PCR-based mutagenesis. The cloning procedure can be obtained upon request. Stable transfectants in AS cells were produced as described (Sleeman et al. 1997).

The constructs secreting the soluble extracellular portion of CD44 (either CD44s or CD44v4-7415) have been described (Morrison et al. 2001).

The soluble GST-CD44 wild-type and mutant cytoplasmic tail expression constructs were obtained from Dr. C. Isacke (London; Legg and Isacke 1998; also described in Morrison et al. 2001). The hemagglutinin-tagged Erk1 plasmid was a gift from Dr A. Ulrich (Martinsried, Germany).

\section{Antibodies and other reagents}

The anti-human CD44v6 antibody BIWA was from Bender. The rat CD44v6-specific antibody 1.1ASML (Matzku et al. 1989) and the 5G8 antibody recognizing the peptide DGDSSMDPRG encoded by exon 15 (Sleeman et al. 1996a) were prepared from hybridomas. The pan-CD44 antibodies IM7 and J173 were from Pharmingen and Immunotech, respectively. Antibodies against Met (sc-161 human) and (sc-8057 mouse), HGF $\alpha$ (sc-7949), and Erk (K-23) antibody were from Santa Cruz. Antibodies against phospho-Erk were from NEB; those against Gabl and phosphotyrosine (4G10) from BIOMOL; rabbit IgG from DIANOVA; rat IgG2b' from Pharmingen, DHS (3G10) from Seigaku, and hemagglutinin (12CA5) from Roche Diagnostics. Hermes3 was a gift from Sirpa Jalkanen (Turku, Finland).

The heparinase II preparation was from Sigma; HGF from R\&D Systems. If not otherwise specified, HGF was preactivated with $5 \%$ serum at $37^{\circ} \mathrm{C}$ overnight. For expression of HGF in Drosophila Schneider S2 cells, the plasmid pBATSFtag containing the HGF coding sequence (gift from Dr. W. Birchmeier, $\mathrm{MDCK}$ ) was cut with $\mathrm{XbaI}$, and the coding sequence cloned into the Drosophila expression vector pAcv5hisB (Invitrogen). The pAcHGF vector was then transiently transfected into Drosophila S2 Schneider cells using the calcium chloride transfection method. The growth medium of the transfectants was used as a source of pro-HGF.

Biotinylation of carrier-free HGF was performed using the Ez-link sulfo-NHS-LC-biotinylation kit (Pierce), following the manufacturer's instructions. The yield of the biotinylation reaction was estimated by Western blot analysis with the HGF $\alpha$ antibody and comparison to known amounts of nonbiotinylated HGF. For specific detection of biotinylated proteins, neutravidin (Pierce) was used (1/1000 dilution in Western blot).

\section{Immunoprecipitation and Western blotting}

Met phosphorylation was measured by immunoprecipitation of Met followed by Western blotting with the phosphotyrosinespecific antibody 4G10. Cells were seeded at a concentration of $3 \times 10^{5}$ cells per $10-\mathrm{cm}$ plate, starved for $24 \mathrm{~h}$, induced with $\mathrm{HGF}(50 \mathrm{ng} / \mathrm{mL})$ at $37^{\circ} \mathrm{C}$ for $5 \mathrm{~min}$, and lysed in lysis buffer $(30$ $\mathrm{mM}$ Tris- $\mathrm{HCl}$ at $\mathrm{pH} 7.4,150 \mathrm{mM} \mathrm{NaCl}, 1 \mathrm{mM}$ EDTA, 0.5\% Triton X100, 0.5\% Na deoxycholate, $10 \mathrm{mM} \mathrm{NaF}, 1 \mathrm{mM}$ PMSF, $1 \mathrm{mM}$ Na-orthovanadate, $1 \mathrm{mM}$ aprotinin, and leupeptin) for 30 min. Immunoprecipitation was performed with the cleared lysates $(12,000 \mathrm{rpm}$ for $15 \mathrm{~min}$ with Met antibodies and protein A/G agarose (Oncogene) at $4^{\circ} \mathrm{C}$ overnight. The precipitates were washed in lysis buffer $(3 \times)$ and once with $20 \mathrm{mM}$ Tris at $\mathrm{pH} 7.5$, $1 \mathrm{mM}$ EDTA at $\mathrm{pH} 8$, and solubilized in boiling SDS-sample buffer containing dithiothreitol (100 mM). Samples were subjected to Western analysis using the anti-phosphotyrosine antibody 4G10. As loading control, the blots were stripped, reprobed with the Met-specific antibody, and finally stained using the enhanced chemiluminescence system (ECL; Amersham). Where specified, the cells were incubated (prior to HGF activation) with anti-CD44 antibodies at $37^{\circ} \mathrm{C}$ either for $5 \mathrm{~min}$ (for BIWA, IM7, J173) or on ice for $30 \mathrm{~min}$ (for 1.1ASML or 5G8).

Phosphorylation of tagged Erk or Gabl was detected upon immunoprecipitation in $50 \mathrm{mM}$ Hepes at $\mathrm{pH} 7.5,150 \mathrm{mM}$ $\mathrm{NaCl}, 1 \%$ Triton together with the inhibitors used in the Met immunoprecipitation buffer with the anti-hemagglutinin or the anti-Gab1 antibody, followed by Western blotting with the phospho-Erk or the phosphotyrosine-specific antibody.

For direct Western blotting of phospho-Erk, the cells were seeded in a 24-well plate of $10^{5}$ cells per well induced with HGF as described above, and directly dissolved in sample buffer.

\section{Cross-linking and exon-specific RT-PCR analysis}

Cross-linking of proteins on cells (10-cm plates) was performed in $2 \mathrm{~mL}$ of PBS plus $3 \mathrm{mg}$ of DTSSP at room temperature for 1 $\mathrm{h}$. The reaction was stopped using $40 \mu \mathrm{L}$ of $20 \mathrm{mM}$ Tris- $\mathrm{HCl}$ at 
$\mathrm{pH}$ 7.4. The cells were then washed; lysed with $25 \mathrm{mM}$ HEPES at $\mathrm{pH} 7.4,100 \mathrm{mM} \mathrm{NaCl}, 5 \mathrm{mM} \mathrm{MgCL}_{2}, 1 \mathrm{mM}$ EGTA, $10 \%$ glycerol, $1.25 \%$ CHAPS (Sigma), proteinase-inhibitor-mix (5 $\mu \mathrm{L} / \mathrm{mL}$; Complete, Roche); and proteins were immunoprecipitated under standard conditions with either Met-specific antibody and protein A/G beads (Oncogene), or CD44-specific antibody IM7 and protein G agarose beads (Oncogene), or HGF $\alpha$ specific antibody and protein A agarose beads (Oncogene).

Exon-specific RT-PCR was performed as described (van Weering et al. 1993). The primers were identical to those used by König et al. (1996).

\section{Chemotaxis and scattering assays}

Chemotaxis assays were performed in 12-well transwell units with 12-um pore filters (Costar). The filters were coated with Matrigel $\left(70 \mu \mathrm{g}\right.$ per filter incubated at $37^{\circ} \mathrm{C}$ for $\left.1 \mathrm{~h}\right)$. The lower well compartment of the transwell unit contained either $600 \mu \mathrm{L}$ RPMI medium (for control) or RPMI together with HGF (50 $\mathrm{ng} / \mathrm{mL}$ ). Then, $2 \times 10^{5}$ cells in $650 \mu \mathrm{L}$ of RPMI were placed in the upper compartment of the transwell unit. After $6 \mathrm{~h}$ of incubation at $37^{\circ} \mathrm{C}$, cells on the upper surface of the filter were removed by wiping with a cotton swab. Remaining cells in the Matrigel and at the filter surface facing the lower chamber were fixed in ethanol $(70 \%)$, stained with crystal violet $0.1 \%$, and lysed with acetic acid, and the OD was measured with an ELISA reader. Where indicated, cells were incubated with antiCD44v6 antibodies on ice for $30 \mathrm{~min}$ prior to the assay.

Scattering of HT29 cells was determined in 24-well plates. First, $4.5 \times 10^{4}$ cells were seeded at $37^{\circ} \mathrm{C}$; the cells were either left untreated (control) or $48 \mathrm{~h}$ later treated with HGF $(50 \mathrm{ng} /$ $\mathrm{mL})$ for $24 \mathrm{~h}$ or with CD44v6 antibodies $(50 \mu \mathrm{g} / \mathrm{mL})$ prior to induction with HGF for $30 \mathrm{~min}$.

\section{Acknowledgments}

The experimental contribution of Jan Adam is highly appreciated. We are grateful for technical help from Giuseppina Pace. This work was supported by DFG grant He 551/10-1.

The publication costs of this article were defrayed in part by payment of page charges. This article must therefore be hereby marked "advertisement" in accordance with 18 USC section 1734 solely to indicate this fact.

\section{References}

Bardelli, A. and Comoglio, P.M. 1997. Scatter factor receptors are key players in a unique multistep program leading to invasive growth. Ciba Found. Symp. 212: 133-144.

Bardelli, A., Pugliese, L., and Comoglio, P.M. 1997. "Invasivegrowth" signaling by the Met/HGF receptor: The hereditary renal carcinoma connection. Biochim. Biophys. Acta 1333: 41-51.

Behrens, J., Mareel, M.M., Van Roy, F.M., and Birchmeier, W. 1989. Dissecting tumor cell invasion: Epithelial cells acquire invasive properties after the loss of uvomorulin-mediated cell-cell adhesion. J. Cell. Biol. 108: 2435-2447.

Bennett, K.L., Jackson, D.G., Simon, J.C., Tanczos, E., Peach, R., Modrell, B., Stamenkovic, I., Plowman, G., and Aruffo, A. 1995. CD44 isoforms containing exon v3 are responsible for the presentation of heparin-binding growth factor. J. Cell. Biol. 128: 687-698.

Birchmeier, C. and Gherardi, E. 1998. Developmental roles of HGF/SF and its receptor, the c-Met tyrosine kinase. Trends Cell Biol. 8: 404-410.
Bourguignon, L.Y., Zhu, H., Chu, A., Iida, N., Zhang, L., and Hung, M.C. 1997. Interaction between the adhesion receptor, CD44, and the oncogene product, p185HER2, promotes human ovarian tumor cell activation. I. Biol. Chem. 272: 27913-27918.

Bourguignon, L.Y., Zhu, H., Shao, L., and Chen, Y.W. 2001. CD44 interaction with c-Src kinase promotes cortactin-mediated cytoskeleton function and hyaluronic acid-dependent ovarian tumor cell migration. J. Biol. Chem. 276: 7327-7336.

Camenisch, T.D., Spicer, A.P., Brehm-Gibson, T., Biesterfeldt, J., Augustine, M.L., Calabro Jr., A., Kubalak, S., Klewer, S.E., and McDonald, J.A. 2000. Disruption of hyaluronan synthase-2 abrogates normal cardiac morphogenesis and hyaluronan-mediated transformation of epithelium to mesenchyme. J. Clin. Invest. 106: 349-360.

Cavallaro, U., Niedermeyer, J., Fuxa, M., and Christofori, G. 2001. N-CAM modulates tumour-cell adhesion to matrix by inducing FGF-receptor signalling. Nat. Cell Biol. 3: 650-657.

Crepaldi, T., Gautreau, A., Comoglio, P.M., Louvard, D., and Arpin, M. 1997. Ezrin is an effector of hepatocyte growth factor-mediated migration and morphogenesis in epithelial cells. J. Cell. Biol. 138: 423-434.

Fazioli, F., Wong, W.T., Ullrich, S.J., Sakaguchi, K., Appella, E., and Di Fiore, P.P. 1993. The ezrin-like family of tyrosine kinase substrates: Receptor-specific pattern of tyrosine phosphorylation and relationship to malignant transformation. Oncogene 8: 1335-1345.

Fisher, P.B., Babiss, L.E., Weinstein, I.B., and Ginsberg, H.S. 1982. Analysis of type 5 adenovirus transformation with a cloned rat embryo cell line (CREF). Proc. Natl. Acad. Sci. 79: 3527-3531.

Fujisaki, T., Tanaka, Y., Fujii, K., Mine, S., Saito, K., Yamada, S., Yamashita, U., Irimura, T., and Eto, S. 1999. CD44 stimulation induces integrin-mediated adhesion of colon cancer cell lines to endothelial cells by up-regulation of integrins and c-Met and activation of integrins. Cancer Res. 59: 4427-4434.

Giordano, S., Zhen, Z., Medico, E., Gaudino, G., Galimi, F., and Comoglio, P.M. 1993. Transfer of motogenic and invasive response to scatter factor/hepatocyte growth factor by transfection of human MET protooncogene. Proc. Natl. Acad. Sci. 90: 649-653.

Günthert, U., Hofmann, M., Rudy, W., Reber, S., Zöller, M., Haußmann, I., Matzku, S., Wenzel, A., Ponta, H., and Herrlich, P. 1991. A new variant of glycoprotein CD44 confers metastatic potential to rat carcinoma cells. Cell 65: 13-24.

Habets, G.G., Scholtes, E.H., Zuydgeest, D., van der Kammen, R.A., Stam, J.C., Berns, A., and Collard, J.G. 1994. Identification of an invasion-inducing gene, Tiam-1, that encodes a protein with homology to GDP-GTP exchangers for Rho-like proteins. Cell 77: 537-549.

Hartmann, G., Prospero, T., Brinkmann, V., Ozcelik, C., Winter, G., Hepple, J., Batley, S., Bladt, F., Sachs, M., Birchmeier, C., et al. 1998. Engineered mutants of HGF/SF with reduced binding to heparan sulphate proteoglycans, decreased clearance and enhanced activity in vivo. Curr. Biol. 8: 125-134. (Erratum published in: 1998. Curr. Biol. 8: R739.)

Hobson, J.P., Rosenfeldt, H.M., Barak, L.S., Olivera, A., Poulton, S., Caron, M.G., Milstien, S., and Spiegel, S. 2001. Role of the sphingosine-1-phosphate receptor EDG-1 in PDGF-induced cell motility. Science 291: 1800-1803.

Hofmann, M., Rudy, W., Gunthert, U., Zimmer, S.G., Zawadzki, V., Zoller, M., Lichtner, R.B., Herrlich, P., and Ponta, H. 1993. A link between ras and metastatic behavior of tumor cells: Ras induces CD44 promoter activity and leads to low-level expression of metastasis-specific variants 
of CD44 in CREF cells. Cancer Res. 53: 1516-1521.

Hudson, D.L., Sleeman, J., and Watt, F.M. 1995. CD44 is the major peanut lectin-binding glycoprotein of human epidermal keratinocytes and plays a role in intercellular adhesion. J. Cell. Sci. 108: 1959-1970.

Katagiri, Y.U., Sleeman, J., Fujii, H., Herrlich, P., Hotta, H., Tanaka, K., Chikuma, S., Yagita, H., Okumura, K., Murakami, M., et al. 1999. CD44 variants but not CD44s cooperate with $\beta 1$-containing integrins to permit cells to bind to osteopontin independently of arginine-glycine-aspartic acid, thereby stimulating cell motility and chemotaxis. Cancer Res. 59: 219-226.

Kaya, G., Rodriguez, I., Jorcano, J.L., Vassalli, P., and Stamenkovic, I. 1997. Selective suppression of CD44 in keratinocytes of mice bearing an antisense CD44 transgene driven by a tissue-specific promoter disrupts hyaluronate metabolism in the skin and impairs keratinocyte proliferation. Genes \& Dev. 11: 996-1007.

Khaldoyanidi, S., Karakhanova, S., Sleeman, J., Herrlich, P., and Ponta, H. 2002. CD44 variant-specific antibodies trigger hemopoiesis by selective release of cytokines from bone marrow macrophages. Blood 99: 3955-3961.

König, H., Moll, J., Ponta, H., and Herrlich, P. 1996. Transacting factors regulate the expression of CD44 splice variants. EMBO I. 15: 4030-4039.

König, H., Ponta, H., and Herrlich, P. 1998. Coupling of signal transduction to alternative pre-mRNA splicing by a composite splice regulator. EMBO J. 10: 2904-2913.

Kulas, D.T., Goldstein, B.J., and Mooney, R.A. 1996. The transmembrane protein-tyrosine phosphatase LAR modulates signaling by multiple receptor tyrosine kinases. J. Biol. Chem. 271: 748-754.

Legg, J.W. and Isacke, C.M. 1998. Identification and functional analysis of the ezrin-binding site in the hyaluronan receptor, CD44. Curr. Biol. 8: 705-708.

Matzku, S., Komitowski, D., Mildenberger, M., and Zoller, M. 1983. Characterization of BSp73, a spontaneous rat tumor and its in vivo selected variants showing different metastasizing capacities. Invasion Metastasis 3: 109-123.

Matzku, S., Wenzel, A., Liu, S., and Zoller, M. 1989. Antigenic differences between metastatic and nonmetastatic BSp73 rat tumor variants characterized by monoclonal antibodies. Cancer Res. 49: 1294-1299.

Medico, E., Gentile, A., Lo Celso, C., Williams, T.A., Gambarotta, G., Trusolino, L., and Comoglio, P.M. 2001. Osteopontin is an autocrine mediator of hepatocyte growth factor-induced invasive growth. Cancer Res. 61: 5861-5868.

Mizuno, K., Inoue, H., Hagiya, M., Shimizu, S., Nose, T., Shimohigashi, Y., and Nakamura, T. 1994. Hairpin loop and second kringle domain are essential sites for heparin binding and biological activity of hepatocyte growth factor. J. Biol. Chem. 269: 1131-1136.

Morrison, H., Sherman, L.S., Legg, J., Banine, F., Isacke, C., Haipek, C.A., Gutmann, D.H., Ponta, H., and Herrlich, P. 2001. The NF2 tumor suppressor gene product, merlin, mediates contact inhibition of growth through interactions with CD44. Genes \& Dev. 15: 968-980.

Naka, D., Ishii, T., Yoshiyama, Y., Miyazawa, K., Hara, H., Hishida, T., and Kidamura, N. 1992. Activation of hepatocyte growth factor by proteolytic conversion of a single chain form to a heterodimer. J. Biol. Chem. 267: 20114-20119.

Naldini, L., Tamagnone, L., Vigna, E., Sachs, M., Hartmann, G., Birchmeier, W., Daikuhara, Y., Tsubouchi, H., Blasi, F., and Comoglio, P.M. 1992. Extracellular proteolytic cleavage by urokinase is required for activation of hepatocyte growth factor/scatter factor. $E M B O T$. 11: 4825-4833.
Naor, D., Sionov, R.V., and Ish-Shalom, D. 1997. CD44: Structure, function and association with the malignant process. In Advances in cancer research (eds. G.F. Vande Woude and G. Klein), pp. 243-318. Academic Press, San Diego, CA.

Nestl, A., Von Stein, O.D., Zatloukal, K., Thies, W.G., Herrlich, P., Hofmann, M., and Sleeman, J.P. 2001. Gene expression patterns associated with the metastatic phenotype in rodent and human tumors. Cancer Res. 61: 1569-1577.

Plotnikov, A.N., Schlessinger, J., Hubbard, S.R., and Mohammadi, M. 1999. Structural basis for FGF receptor dimerization and activation. Cell 98: 641-650.

Ponta, H. and Herrlich, P. 1998. The CD44 protein family: Roles in embryogenesis and tumor progression. Front. Biosci. 3: d650-d656.

Ponta, H., Wainwright, D., and Herrlich, P. 1998. The CD44 protein family. Int. J. Biochem. Cell. Biol. 30: 299-305.

Protin, U., Schweighoffer, T., Jochum, W., and Hilberg, F. 1999. CD44-deficient mice develop normally with changes in subpopulations and recirculation of lymphocyte subsets. I. Immunol. 163: 4917-4923.

Reeder, J.A., Gotley, D.C., Walsh, M.D., Fawcett, J., and Antalis, T.M. 1998. Expression of antisense CD44 variant 6 inhibits colorectal tumor metastasis and tumor growth in a wound environment. Cancer Res. 58: 3719-3726.

Rodrigues, G.A. and Park, M. 1993. Dimerization mediated through a leucine zipper activates the oncogenic potential of the met receptor tyrosine kinase. Mol. Cell. Biol. 13: 67116722.

Rong, S., Segal, S., Anver, M., Resau, J.H., and Vande Woude, G.F. 1994. Invasiveness and metastasis of NIH 3 T3 cells induced by Met-hepatocyte growth factor/scatter factor autocrine stimulation. Proc. Nat1. Acad. Sci. 91: 4731-4735.

Rudy, W., Hofmann, M., Schwartz-Albiez, R., Zoller, M., Heider, K.H., Ponta, H., and Herrlich, P. 1993. The two major CD44 proteins expressed on a metastatic rat tumor cell line are derived from different splice variants: Each one individually suffices to confer metastatic behavior. Cancer Res. 53: 1262-1268.

Schlessinger, J., Lax, I., and Lemmon, M. 1995. Regulation of growth factor activation by proteoglycans: What is the role of the low affinity receptors? Cell 83: 357-360.

Schmits, R., Filmus, J., Gerwin, N., Senaldi, G., Kiefer, F., Kundig, T., Wakeham, A., Shahinian, A., Catzavelos, C., Rak, J., et al. 1997. CD44 regulates hematopoietic progenitor distribution, granuloma formation, and tumorigenicity. Blood 90: 2217-2233.

Seiter, S., Arch, R., Reber, S., Komitowski, D., Hofmann, M., Ponta, H., Herrlich, P., Matzku, S., and Zoller, M. 1993. Prevention of tumor metastasis formation by anti-variant CD44. J. Exp. Med. 177: 443-455.

Sherman, L., Wainwright, D., Ponta, H., and Herrlich, P. 1998. A splice variant of CD44 expressed in the apical ectodermal ridge presents fibroblast growth factors to limb mesenchyme and is required for limb outgrowth. Genes \& Dev. 12: 10581071.

Sherman, L.S., Rizvi, T.A., Karyala, S., and Ratner, N. 2000. CD44 enhances neuregulin signaling by Schwann cells. I. Cell. Biol. 150: 1071-1084.

Sleeman, J.P., Arming, S., Moll, J.F., Hekele, A., Rudy, W., Sherman, L.S., Kreil, G., Ponta, H., and Herrlich, P. 1996a. Hyaluronate-independent metastatic behavior of CD44 variantexpressing pancreatic carcinoma cells. Cancer Res. 56: $3134-3141$.

Sleeman, J., Rudy, W., Hofmann, M., Moll, J., Herrlich, P., and Ponta, H. 1996b. Regulated clustering of variant CD44 proteins increases their hyaluronate binding capacity. J. Cell. 
Biol. 135: 1139-1150.

Sleeman, J., Kondo, K., Moll, J., Ponta, H., and Herrlich, P. 1997. Variant exons $\mathrm{v} 6$ and $\mathrm{v} 7$ together expand the repertoire of glycosaminoglycans bound by CD44. I. Biol. Chem. 272: 31837-31844.

Tanaka, Y., Adams, D.H., Hubscher, S., Hirano, H., Siebenlist, U., and Shaw, S. 1993. T-cell adhesion induced by proteoglycan-immobilized cytokine MIP-1b. Nature 361: 79-82.

Trowbridge, I.S., Lesley, J., Schulte, R., Hyman, R., and Trotter, J. 1982. Biochemical characterization and cellular distribution of a polymorphic, murine cell-surface glycoprotein expressed on lymphoid tissues. Immunogenetics 15: 299-312.

Trusolino, L., Bertotti, A., and Comoglio, P.M. 2001. A signaling adapter function for alpha6beta4 integrin in the control of HGF-dependent invasive growth. Cell 107: 643-654.

Tsukita, S. and Yonemura, S. 1999. Cortical actin organization: Lessons from ERM (ezrin/radixin/moesin) proteins. J. Biol. Chem. 274: 34507-34510.

van der Voort, R., Manten-Horst, E., Smit, L., Ostermann, E., van den Berg, F., and Pals, S.T. 1995. Binding of cell-surface expressed CD44 to hyaluronate is dependent on splicing and cell type. Biochem. Biophys. Res. Comm. 214: 137-144.

van der Voort, R., Taher, T.E., Wielenga, V.J., Spaargaren, M., Prevo, R., Smit, L., David, G., Hartmann, G., Gherardi, E., and Pals, S.T. 1999. Heparansulfate-modified CD44 promotes hepatocyte growth factor/scatter factor-induced signal transduction through the receptor tyrosine kinase c-Met. J. Biol. Chem. 274: 6499-6506.

van Weering, D.H., Baas, P.D., and Bos, J.L. 1993. A PCR-based method for the analysis of human CD44 splice products. PCR Methods Appl. 3: 100-106.

Vasioukhin, V., Bauer, C., Degenstein, L., Wise, B., and Fuchs, E. 2001. Hyperproliferation and defects in epithelial polarity upon conditional ablation of alpha-catenin in skin. Cell 104: 605-617.

Vigna, E., Gramaglia, D., Longati, P., Bardelli, A., and Comoglio, P.M. 1999. Loss of the exon encoding the juxtamembrane domain is essential for the oncogenic activation of TPRMET. Oncogene 18: 4275-4281.

Villa-Moruzzi, E., Puntoni, F., Bardelli, A., Vigna, E., De Rosa, S., and Comoglio, P.M. 1998. Protein tyrosine phosphatase PTP-S binds to the juxtamembrane region of the hepatocyte growth factor receptor Met. Biochem. J. 336: 235-239.

Whitmarsh, A.J., Cavanagh, J., Tournier, C., Yasuda, J., and Davis, R.J. 1998. A mammalian scaffold complex that selectively mediates MAP kinase activation. Science 281: 16711674.

Yasuda, J., Whitmarsh, A.J., Cavanagh, J., Sharma, M., and Davis, R.J. 1999. The JIP group of mitogen-activated protein kinase scaffold proteins. Mol. Cell. Biol. 19: 7245-7254.

Yu, Q. and Stamenkovic, I. 1999. Localization of matrix metalloproteinase 9 to the cell surface provides a mechanism for CD44-mediated tumor invasion. Genes \& Dev. 13: 35-48. 


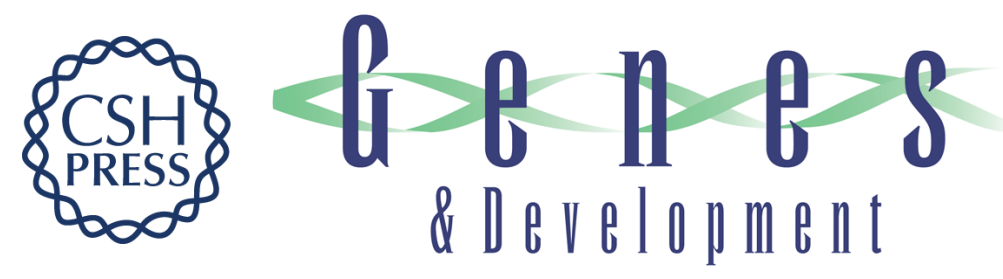

\section{CD44 is required for two consecutive steps in HGF/c-Met signaling}

Véronique Orian-Rousseau, Linfeng Chen, Jonathan P. Sleeman, et al.

Genes Dev. 2002, 16:

Access the most recent version at doi:10.1101/gad.242602

Supplemental Material

References

This article cites 63 articles, 38 of which can be accessed free at: http://genesdev.cshlp.org/content/16/23/3074.full.html\#ref-list-1

\section{License}

Email Alerting Service

http://genesdev.cshlp.org/content/suppl/2002/12/09/16.23.3074.DC1 right corner of the article or click here.

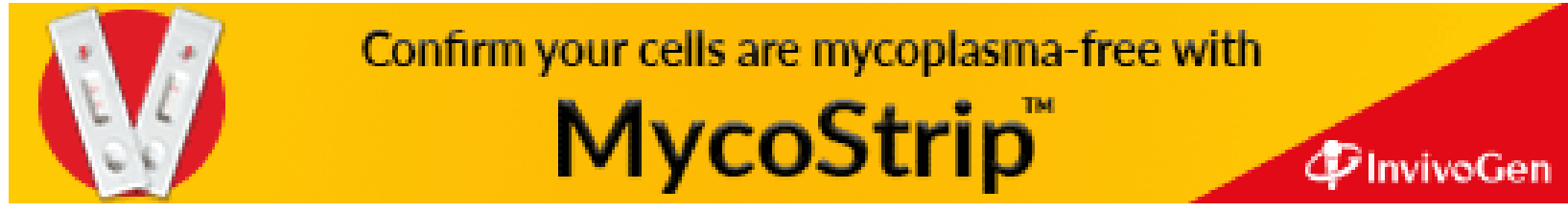

